\title{
Anti-Americanism in Turkey: Past and Present
}

\section{aylin Güney}

To cite this article: aylin Güney (2008) Anti-Americanism in Turkey: Past and Present, Middle Eastern Studies, 44:3, 471-487, DOI: 10.1080/00263200802021632

To link to this article: https://doi.org/10.1080/00263200802021632

曲 Published online: 21 May 2008.

Submit your article to this journal $2 \pi$

III Article views: 627

4 Citing articles: 8 View citing articles 


\title{
Anti-Americanism in Turkey: Past and Present
}

\author{
AYLIN GÜNEY
}

After the Second World War, strategic collaboration between Turkey and the United States (USA) was not established on an already-existing relationship, since neither the USA nor Turkey had important strategic interests in one another during the interwar years (1919-39). Nevertheless, the interwar period had laid the groundwork and provided a logical basis for such cooperation. Prior to the First World War, Americans had already built up interests, mainly of a philanthropic and commercial nature, in the Middle East and the Eastern Mediterranean.

At that time, American interests in Turkey included the Turkish missions of the Congressional American Board, trade and business, technical assistance furnished by individual Americans and private organizations, non-missionary philanthropy and other cultural enterprises, and archaeological expeditions sponsored by American universities. $^{1}$

In the aftermath of the First World War, another factor became increasingly important for American interests in the Middle Eastern and Eastern Mediterranean region in addition to philanthropic interests. It was the Middle East's vast oil reserves, capable of supplying 75-80 per cent of all Western oil demand. ${ }^{2}$ Thus, Turkey started to be evaluated within the framework of the Middle East's increasing strategic importance. For example, an early draft of what became the Truman Doctrine stressed Turkey's proximity to the 'great natural resources' of the Persian Gulf. Turkey's geo-strategic location was of considerable importance to US interests since it could serve as a major base for US power projection into the Middle East in order to be able to secure the flow of oil.

American interest in oil and its 'open door' policy for any business interest that wanted to operate in the Middle East was controversial, and in some respects constituted the first divergence of interests between the two countries. De Novo gives an example of this clash of interests: 'even in the event of the rumoured political deal whereby Great Britain would let Turkey have Mosul, ${ }^{3}$ the USA would oppose any monopolistic concession in the area'.

The beginning of the Cold War period (1947) marked a different phase in TurkishAmerican relations. The Truman Doctrine highlighted the convergent strategic interests between Turkey and the USA, and Turkey's geo-strategic importance for the West became an asset for Turkey. Turkey became one of the beneficiaries of the Marshall Plan, which directed an extensive amount of economic aid to the country. Turkey's main objective was to attract US attention to the Eastern Mediterranean 
and involve it in the defence of Turkey against the Soviet Union since Turkey's defensive resources were limited due to the country's economic difficulties. Turkey's participation in the Korean War in 1950 revealed Turkey's willingness to become a part of the Western world and contributed greatly to the decision to include Turkey within the NATO framework. In the 1950s, Turkey concluded several bilateral agreements with the USA which allowed American armed forces to use Turkish territory and establish facilities called 'Joint Defence Installations'. These installations (over 30, with 5,000 US personnel) would collectively engage in defence missions that ranged from basic logistics and supply operations to highly sophisticated communications and intelligence-gathering activities. ${ }^{5}$ To give one illustration of the intensity of the relationship, Metin Toker recounts that 'while making an inventory of the American bases in Turkey after 1960, it was discovered that some of them were not even on record' ${ }^{6}$ The 1950 s were also years in which US popular culture was disseminated to a great extent since one of the objectives of Adnan Menderes, the prime minister was, as Celal Bayar puts it, 'creating a little America'. Except for a few negligible events, Turkish public opinion had no negative perception of or attitude towards the USA. ${ }^{7}$

The first temporary irritant signalling the beginning of some problems was the American's removal of Jupiter missiles from Turkey in the aftermath of the 1962 Cuban missile crisis without prior consultation with Ankara. The main reason that Turkish decision-makers wanted strategic nuclear missiles on Turkish territory was the hope of increasing America's strategic dependence on Turkey. This was despite the obvious risk of causing problems with and being the potential nuclear target of a neighbouring country in case of a war, and despite the fact that weapons of mass destruction are not necessarily useful to defend a particular territory. ${ }^{8}$

It appeared to the public at large that 'the Kennedy administration had been bargaining a deal and if the Soviets agreed to withdraw its missiles from Cuba, within a short time after the crisis was over, the Jupiters would be gone'. ${ }^{9}$ By 1964 the Soviet embassy in Ankara had leaked information about this US-Soviet bargain. Although the Turkish and American governments denied it, leftists in Turkey believed it wholeheartedly. By the time scholars could verify such a bargain about 25 years later, the issue had made its way into a Hollywood movie, Thirteen Days. The crisis was over, but the rumour of a bargain contributed to the polarization of the Turkish Right and Left over the American presence. ${ }^{10}$

The Turks had put a great deal of money into the missiles' installation and they were regarded as a guarantee for the nation's security. Therefore, although some political circles in Turkey were relieved by the removal of the Soviet threat, Turkish public opinion turned anti-American because the Turks made this issue a 'matter of honour' and began to question the trust and reliability of the commitments in the alliance. At any rate, the Cuban missile crisis made Turkey realize that in future 'a decision by Washington might jeopardize her safety and even her existence'. ${ }^{11}$ The way Turkey was treated by the USA during the crisis led to criticism against the American influence which 'so much monopolized the foreign policy of Turkey'. ${ }^{2}$

The 'opium issue' was also a major example of divergent interests between Turkey and the USA during the Cold War period. Although there was no problem regarding the production of opium in Turkey between 1945 and the mid-1960s, after drug abuse started to emerge as a matter of intense concern in American domestic politics, 
opium production became an important bone of contention in Turkish-American relations.

For Turkey, opium use was almost non-existent among both the youth and the poppy growers. In fact, the poppy growers earned more selling their product to the government legally. However, the US Bureau of Narcotics and Dangerous Drugs gradually reached the conclusion that 'about 80 per cent of the heroin illicitly introduced into the United States was derived from opium diverted from Turkish production'. ${ }^{13}$ As a result, the Johnson administration wanted Turkey to shut off that illicit supply. Although production was cut to a certain extent, the issue became more serious - especially with Attorney General John Mitchell's qualified approval, on 20 July 1970, of economic sanctions to shut off the opium traffic from various countries, including Turkey.

The problem was solved when Washington achieved a complete ban on opium production, in return for which it agreed to give Turkey US\$35 million over a threeyear period. However, the deal did not prevent the relationship from deteriorating because public opinion in Turkey was not satisfied with the amount of financial assistance the USA was to extend and the press regarded the agreement as an interference in Turkey's domestic politics. The rising tide of anti-Americanism was revealed in street demonstrations organized by the peasants as well as newspaper articles by left-wing columnists. ${ }^{14}$

Relations between Turkey and the USA hit rock bottom with the Cyprus crisis of 1963 and the subsequent 'Johnson Letter' that was sent to Prime Minister İnönü. After Cyprus became an independent state in 1960, the Greek Cypriots tried to revise the constitution in their favour since they had never accepted the provisions of the London and Zurich Agreements that had excluded the Cypriots in its drafting. They thought that it was an order that was imposed from outside by an agreement between Great Britain, Turkey and Greece. As a result, the constitutional order was destroyed and intercommunal conflict started between the two communities. As the conflict became more and more violent to the point of threatening the existence of the Turkish Cypriots on the island, the Turkish government decided to send troops to Cyprus to protect the Turkish community from the attacks of the Greek Cypriots.

This decision of Turkey alarmed the USA, and President Lyndon Johnson sent a strongly worded letter to Prime Minister İsmet İnönü:

I must call to your attention the obligations of NATO. There can be no question in your mind that a Turkish intervention in Cyprus would lead to a military engagement between the Turkish and Greek forces ... Adhesion to NATO, in its very essence, means that NATO countries will not wage war on each other. Furthermore, a military intervention in Cyprus could lead to direct involvement by the Soviet Union. I hope you will understand that your NATO allies have not had the chance to consider whether they have an obligation to protect Turkey against the Soviet Union if Turkey takes a step which results in Soviet intervention without the full consent and understanding of its NATO allies. ${ }^{15}$

As a result, the Turkish government changed its mind and did not send the troops. Although the Johnson letter was not made public for the next 18 months, its contents were partially leaked to the Turkish press soon after its receipt. Turkey, at both the 
level of official and public opinion, was shocked by the Johnson letter's harsh tone ${ }^{16}$ and particularly by the indication that the alliance might not necessarily act against the Soviets. This led to further questioning of the reliability of American commitments to Turkey, and a wave of public protests against the US ensued. The Johnson letter, along with other factors, was instrumental in ushering in antiAmericanism in Turkey.

Following the Cyprus dispute, persistent public questioning of American motives began $^{17}$ and there was a sharp increase in anti-American sentiment and antiAmerican protests in Turkey. A variety of accusations started to be levelled against the US, especially concerning the American military presence and the bilateral agreements that had impinged on Turkish sovereignty whereby the US was seen as interfering in Turkish domestic affairs. That is, anti-American sentiment had other causes as well as the Cyprus issue, which ultimately led people of all political leanings to take to the streets to protest at the American role in blocking Turkey. Some Turks, especially the radical left, were against the USA because they regarded American foreign policy as imperialistic. This led to a widespread belief that Turkey's legal system had no discretion to judge American personnel, implying that it had no sovereignty over its own land; that it created colonial dependency under an American mandate; that the US had occupied 35 million square metres of Turkish land through its installations; and that the US controlled Turkish domestic and foreign policy. ${ }^{18}$ The rise of the Turkish Labour Party (TLP) and the radical left, and their anti-American propaganda, led to a general climate of suspicion of the US among Turkish society at large. Vali asserts that the anti-American complaints and accusations were by no means restricted to the American military presence. Some exaggerated and invented grievances were also widespread. These included the 'belief that archaeological treasures were being smuggled out of Turkey and the USIS (United States Information Service) or Peace Corps personnel were involved in espionage activities to an accusation that the Turkish nation is being poisoned by American wheat'. ${ }^{19}$

It is important to emphasize that, during those years, most of the protests came from the left. Despite the resolution of the Cyprus crisis in 1967 in favour of Turkey, and despite the 1969 signing of the Defence Cooperation Agreement, the extreme left increased its agitation against the US. In the universities and public meetings, antiAmerican and anti-NATO slogans became customary. The chief target of the radical left's anti-Americanism became the American presence in Turkey. In late 1967, when Cyrus Vance, the US special emissary to Cyprus, arrived in Turkey as a part of his shuttle diplomacy regarding Cyprus, his aircraft was forced to land at a military airport due to the anti-American demonstrations at the civilian airport. ${ }^{20}$ When the US Sixth Fleet visited Istanbul in 1968, leftist university students protested and some American sailors were thrown into the sea. As a result, Americans tried to make their presence in Turkey less visible and the number of Americans in Turkey, along with the visits of the Sixth Fleet, was progressively reduced. ${ }^{21}$

The defeat of the left-wing political parties in the 1969 elections led to disillusionment in some sections of the radical left regarding the feasibility of succeeding through the parliamentary system. Some of these elements began a campaign of violence and terrorism aimed at the American military presence and personnel by attacking US military installations. In 1969, the car of US Ambassador 
Robert Komer was burnt on the basis that he was a CIA agent involved in a conspiracy to split the left. Likewise, several American military personnel were kidnapped and briefly held in late 1970 and early $1971 .{ }^{22}$ The concern of the USA was that, although the anti-American demonstrators were a minority, they were an elite minority with considerable influence among the press, universities and students. $^{23}$

The last bitter page in Turkish-American relations during the Cold War period was the US arms embargo in December 1974 as a result of the Turkish intervention in Cyprus. Although the administration was strongly opposed to the embargo and did not consider it as an effective tool to achieve US policy objectives in the unstable Eastern Mediterranean, the embargo was implemented. ${ }^{24}$ The embargo lasted for three years and had very negative effects on Turkish-US relations. Although the gradual lifting of the embargo began a year later and ended in 1978, its impact on bilateral relations was devastating. First, the Turks considered it an intrusion into their domestic affairs, and anti-American sentiments grew. Turkey responded by shutting down all American military installations on its territory, including air bases, naval facilities, early warning radar stations and intelligence gathering facilities. Second, Turkey completely lost its confidence in the US. The strategic collaboration was halted for a while, until the US realized the negative consequences of the arms embargo as Soviet pressure increased on Afghanistan and Islamic fundamentalist pressure increased in Iran - two key countries of the US containment strategy during the cold war.

Nur Bilge Criss states that 'one of the most interesting points regarding antiAmericanism in Turkey during the 1970s is that it became a useful tool for domestic terrorism between the radical leftists and ultra-rightists (including the Islamic radicals), but not for terrorism against American citizens'. ${ }^{25}$ Whether antiAmericanism was directed towards an internal struggle, or whether it just spontaneously developed in that direction is not clear. The explanation may either be extremely complex or as simple as the fact that terrorism in Turkey was a war of ideologies ${ }^{26}$ and did not target American residents. More importantly, perhaps, even the most ardent anti-Americanists knew that Turkey had volunteered for NATO membership and opted for the western bloc - it was not a foreign imposition. This may be one distinguishing feature of anti-Americanism $\grave{a}$ la Turca as opposed to anti-Americanism elsewhere in the Near East.

In 1979, the US administration asked Turkey for the use of the Incirlik air base in an attempt to obstruct the Islamic revolution in Iran, and then again to try to rescue American hostages from the US embassy in Tehran. Without any public display, both requests were promptly turned down. That same year, President Jimmy Carter asked the Turkish government for permission for U-2 reconnaissance flights in order to monitor Soviet compliance with the SALT II agreement. Prime Minister Bülent Ecevit insisted that the Soviets had to be informed, which the American interlocutors were not willing to do, so Ankara rejected the proposal (although this then became a non-issue because the US Congress did not ratify SALT II).

The effects of the arms embargo were felt very bitterly by both Turkish statesmen and public opinion. The embargo and the resulting strain in relations led to Turkish disillusionment with the USA. In essence, Turkish security was seen as being held hostage to the vagaries and peculiarities of US domestic politics. ${ }^{27}$ Consequently, 
Turkey made efforts to reorient its exclusively pro-Western and uni-dimensional foreign policy towards a more diversified, flexible, multilateral foreign and economic policy, which it embarked upon in the mid-1960s with its policy of following a more independent course within NATO. As a result, Turkey's diplomatic and political relations with the non-Western world steadily improved.

The 1980s were years when the USA tried to repair relations with the 'forgotten ally'. ${ }^{28}$ The Iranian revolution in 1979 and the subsequent invasion of Afghanistan by the Soviet Union resulted in a reappraisal of the role of Turkey in Western defence and interests. The signing and implementation of the DECA (Defence and Economic Cooperation Agreement), despite the military coup d'état in Turkey on 12 September 1980, was a clear sign of the changed role of Turkey in the eyes of the USA.

In sum, the sources of anti-Americanism in the Cold War period are various. As Vali explains, 'the motivations are both rational and irrational and rely both on tangible and intangible reasons'. ${ }^{29}$ The Turks are characterized by their national pride and national consciousness was very high. The interactions of American and Turkish nationals were hardly felicitous since they came from very different cultural backgrounds. American foreign policy abroad in general, and the Vietnam War in particular, was also influential in shaping Turkish public opinion. The provision of economic aid was considered by Turkey as a duty that the richer nations should provide to the poorer. Therefore, any reduction in aid was perceived as an affront. ${ }^{30}$ It is also important to note that the domestic atmosphere also prepared the ground for expressing these anti-American feelings in a visible manner. The 1961 Constitution is regarded as Turkey's most liberal, which provided freedoms and liberties to a degree that had not been experienced before.

The end of the Cold War, marked by the disintegration of the Soviet Union, opened another phase in Turkish-American relations. ${ }^{31}$ The rise of anti-American sentiment in Turkey coincided with the new threat definition made as early as 1990 by President George Bush, who stated that 'Our enemy is uncertainty and instability'. ${ }^{32}$ This view was further strengthened by Colin Powell, the then Chairman of the Joint Chiefs of Staff, who stated that 'the post-Cold War world will be a more dangerous place for the US than the Cold War world because of the proliferation of weapons of mass destruction in hostile states, anti-American regimes in the Third World, drug traffickers, anti-democratic insurgents and terrorism'. ${ }^{33}$

The US Congress made a major policy change in the early 1990s by ending the grant military aid programme for Turkey, as well as for Portugal and Greece, converting what was previously grant military aid to low interest loans (at not less than 5 per cent interest) for purchases of military equipment; and reducing the overall military aid levels of each of these countries by 10 per cent compared to the previous fiscal year. ${ }^{34}$ The reason for the cut in military aid was very clear from the words of a former member of Congress, Edward Derwinski: 'We provide military assistance to countries only when there is a common military purpose. 35

The most important factor igniting anti-Americanism in Turkey in the 2000s was the war on Iraq, especially the way it was conducted. The war on Iraq, started by the USA in March 2003, had very important repercussions for the long-lasting strategic partnership between the two countries by creating a serious crisis of confidence on both sides and eventually putting the alliance under scrutiny. America's international 
strategy in the aftermath of the events of 11 September 2001 was focused to a great extent on 'preventing rogue states from threatening the USA, its allies and its friends with weapons of mass destruction, and with fighting terrorism, if necessary through pre-emptive strikes'. ${ }^{36}$ In this respect, in Colin Powell's words, the US strategy was one of partnerships that strongly affirmed the vital role of NATO and other US alliances. ${ }^{37}$

Within the framework of this strategy, Turkey was seen as one of the most important forward bases through which these policies would be implemented. Turkey fully supported the American war on Afghanistan aiming to destroy AlQaeda, which was engaged in terrorist activities against the USA. The same Turkish attitude was also expected regarding the subsequent war on Iraq where the Saddam regime was allegedly hiding weapons of mass destruction from international inspection. The high expectations from Turkey by the USA were best revealed in the words of Paul Wolfowitz, the Deputy Defense Secretary, who stated that

Turkish participation, if it does come to the use of force, is very important in managing the consequences, in producing the result as decisively as possible, and also in helping to make sure that post-war Iraq is a positive force in the region, not a destabilizing one. So, it is very crucial to have Turkey intimately involved in the war-planning process. ${ }^{38}$

By invading Iraq from the north as well as the south, the US and its allies hoped to strike at Saddam Hussein's forces from different directions and quickly overwhelm them. From the very beginning, Turkey was suspicious about the American war plans and was reluctant not only to take part in the US-led war but also to ease the latter's military strike on Iraq by opening air bases and borders to coalition troops. The reasons for Turkey's reluctance were manifold and an anti-American stand could be seen for the following reasons.

Firstly, Turkey repeatedly pointed out its economic losses from the first Gulf War in 1991, which had never been fully compensated by the US. Second, Turkey feared that a military strike on Iraq could lead the Kurds to establish an independent state next door. A possible refugee flood (as had previously happened in the first Gulf War) and the possible Kurdish control of the oil-rich cities of Mosul and Kirkuk, where a sizeable Turkoman minority lived, were also serious concerns for Turkey. Therefore, Turkey started increasing its military presence in northern Iraq since it was deemed by the state authorities a necessary measure to protect the country's national interests there and to stop a possible refugee influx in case of a war. ${ }^{39}$

Third, opposition to the war also stemmed from the stance of the newly formed government of the Justice and Development Party (Adalet ve Kalkınma Partisi AKP). The AKP government was facing trouble over the possible operation against Iraq because of pressure from its grassroots. Despite having an overwhelming majority in Parliament with 363 seats, the AKP would have had difficulty passing the decision wanted by the Americans regarding Iraq since it came from an Islamist political tradition which opposes declaring war against a fellow Muslim country. Actually, strong public pressure encouraged the authorities to brush aside talk of negotiations with the USA and launch instead an 'active diplomacy for peace'. ${ }^{40}$ The government stated that diplomatic means for a peaceful solution had not yet been 
exhausted, that the legitimacy of such a war was questionable and that Turkey would wait for the United Nations' final decision. ${ }^{41}$

Influential American newspapers at the time reported on the anti-war sentiments of Turkish people and the indecisiveness of the Turkish government on taking a decision to cooperate with the US in a possible operation against the Iraq regime. In fact, however, the Turkish government's delay in deciding whether to host US troops for a possible invasion of Iraq mainly reflected the deep pessimism among Turks that such a conflict would harm their country politically or economically. A nationwide poll found that 88 per cent of Turks opposed a new war across the south-eastern border, and almost two out of three believed that Turkey should stay out of it if there was one. ${ }^{42}$

Being aware of the fact that Turkey's stance would make a difference in the long term, the US president told the Turkish authorities behind closed doors that their decision to cooperate would be decisive in determining how much Turkey would participate in Iraq's multi-billion restructuring in the aftermath of a possible war. This would provide great economic support to Turkey, still struggling with the aftereffects of a massive economic crisis that had taken place in February 2002. The US reassured the Turks that Congress was willing to pass legislation that would help Turkey absorb any economic shocks by providing a line of credit worth as much as $\$ 14$ billion. Yet the 'carrot policy' was not welcomed either in Turkey or in the US. The offer fuelled scepticism in Turkey since similar, but unfulfilled promises of compensation had been made before the Gulf War of 1991. On the US side, the view was generally that an alliance with a price tag was no alliance at all. If Turkey acted like a strategic ally rather than a nervous renter of bases, it would have an unwavering superpower on its side for decades to come. ${ }^{43}$

The other component of the 'carrot policy' was the revoking of Article 5 of the NATO Treaty, which regulated collective defence of a member coming under attack. The US made a formal request for limited help from the NATO alliance should war break out with Iraq and asked protection for Turkey from the threat of a counter-strike from the Iraqis. NATO's 18-nation Defence Planning Committee agreed to deploy Airborne Warning and Control System (AWACS) early warning aircraft, Patriot air defence missile systems and chemical-biological response units in southern Turkey.

At the end of a round of intense negotiations in the US capital during the same period, the Bush administration offered to expand its aid package, including about $\$ 6$ billion in grants and up to \$20 billion in loan guarantees, to secure Ankara's support for a possible invasion of Iraq. However, Washington demanded that the loans fall under the terms of the International Monetary Fund (IMF)-backed economic programme. This latest package was well above the initial US offer of $\$ 14$ billion, which had included grants and the funds needed to support up to $\$ 10$ billion in loans, and the increase underscored just how important Turkish basing was to US war planners. Yet for Turkey the amount was not sufficient and at one point Ankara asked Washington for close to $\$ 50$ billion in aid - which US officials dismissed as excessive. On the other hand, the USA also started to use the threat of a cancellation of possible military aid to Turkey if Turkey did not immediately allow the US army to deploy troops intended for the strike. ${ }^{44}$

The Turkish leaders, however, reiterated that such a decision would require authorization from the Turkish Parliament and emphasized it would be hard to get 
this in the absence of a clear resolution from the UN Security Council allowing the use of force against Iraq. The lack of a decision by the Turkish government was seen in the US as an indication of uncertainty, or even weakness, in the longstanding alliance and that Turkey was attaching a dollar value to its support for the USA.

On 1 March 2003, the Turkish Parliament rejected a government motion empowering it to allow the deployment in Turkey of foreign troops and to send Turkish troops abroad. Dozens of American ships waiting off Turkey's Mediterranean deep-sea ports started to head to the Persian Gulf after the Pentagon formally abandoned plans to open a northern front through Turkey. The USA also started pulling out logistical stockpiles in south-eastern Turkey. The 'stick policy' of the USA towards Turkey became harsher when President Bush stated that the USA had contingency plans in place if the Turkish Parliament insisted on not allowing in US combat troops, and made a veiled warning to Turkey that it might end up missing its chance to have a say in the future of Iraq and lose a multi-billion dollar aid package to protect its economy from the negative impacts of a war. ${ }^{45}$

Turkey's decision not to pass the bill allowing the deployment of US troops dealt a serious blow to ties between Turkey and the USA. Many people in the American administration were of the opinion that the AKP administration had failed to demonstrate good leadership and even had suspicions that they did not sincerely want to have the motion approved by the party's parliamentary deputies.

Eventually, realizing the serious security risks of non-involvement in northern Iraq, Turkey decided, though with considerable delay, to give partial support to the US to open a northern front against Iraq. In late March 2004, the Parliament voted to pass a government motion allowing the USA to use Turkey's airspace to cross into Iraq for airborne attacks. Overflight rights would not allow the fully fledged northern front that the US had hoped to launch from Turkey, but it would allow warplanes to conduct bombing missions and land special forces in northern Iraq to engage Iraqi forces and to secure the oilfields that Washington feared could be sabotaged. The proposal did not, however, allow US planes to use Turkish airbases or refuel in Turkey. In particular, the US would not be able to use Incirlik airbase, a sprawling facility that already housed the 50 US fighters used to patrol a no-fly zone over Iraq. In the event of a war, fighters at Incirlik would apparently not be able to fly over Iraq.

More importantly, the bill also authorized the Turkish government to dispatch troops to northern Iraq, which became a major issue of contention between the two countries in the following days. The US was alarmed by the statement of Turkish Foreign Minister Abdullah Gül about Turkey sending troops into northern Iraq to protect its national interests, since any fighting between Turkish troops and Kurdish groups could seriously disrupt the US military campaign to topple Saddam and damage their plans to keep a fragmented country together. Regarding a reported warning by US President George W. Bush that a military confrontation between Turkey and the US was possible if Turkey, by itself, sent troops to northern Iraq, ${ }^{46}$ the Turkish Parliament Speaker said, 'Nobody, even if his name is Bush, can talk to the Turkish prime minister or any other state official in a threatening tone'. ${ }^{47} \mathrm{He}$ maintained that Turkey would make decisions on northern Iraq on its own and necessary measures would be taken when the time came. 
While Ankara insisted, in a show of growing discord with the USA, that it would not give up on its plans to send troops to the region, citing national security concerns, Bush said: 'We have got more troops up north, and we're making it very clear that we expect [the Turks] not to come into northern Iraq. ${ }^{48}$ It was also implied that the Turkish military presence in northern Iraq could lead to friendly fire incidents between Turkish and coalition forces, since the friend and foe identification system would not allow the US forces to distinguish Turkish troops from enemy Iraqi forces. A Turkish presence could also lead to clashes with Kurdish groups who were de facto controlling the region. Bush made it clear that a Turkish incursion would not be welcomed and would in turn lead to further strains in Turkey-US ties.

The Turkish Parliament's decision also drew an immediate reaction from Kurdish members of Iraq's Governing Council, whose 24 members had been appointed by the USA. The strong opposition of the Iraqi groups to the deployment of Turkish troops raised doubts about the wisdom of the US proposal to install Turkish peacekeepers in Northern Iraq. In a sign that Washington was drawing closer towards dropping the idea of accepting Turkish troops, Deputy Secretary of Defense Paul Wolfowitz, originally one of the most fervent supporters of a Turkish military contribution, was reported to have admitted that Turkish troops might pose too many risks. ${ }^{49}$

The crisis of confidence deepened - as became evident from the statements of Turkish government officials, who were dissatisfied with the oscillating position of the USA regarding the deployment of troops in Iraq. Turkey criticized the ineptitude of US policy and emphasized that Turkey needed to know very clearly under what conditions its troops would be sent to Iraq. At the same time, Turkey was quite sensitive on the Kurdish issue in northern Iraq and from time to time complained strongly about what it saw as 'preferential' treatment given to the Iraqi Kurds by Washington, stating that 'the USA was giving excessive favours to Kurdish groups in Iraq, at the risk of encouraging civil war and Kurdish secession in the future ... Kurdish representation is far in excess of their real standing in the society'. ${ }^{50}$ Ankara also complained that the Iraqi Turkomans did not get a fair hearing in Washington. ${ }^{51}$ Erdoğan stated that 'Turkey remained opposed to greater autonomy being granted to Kurds in northern Iraq or to any ethnically oriented federation in post-war Iraq'. ${ }^{52}$ Turkey was also concerned that the Kurds wanted to take control of the rich oilfields of Kirkuk, a claim denied by the Kurds. The Kurds said they did not want to run the oilfields but stressed they wanted full guarantees that they would get a share of Iraqi oil revenues to develop their region. The USA had given assurances to Ankara that this would be the case.

Problems in relations were highlighted by a dramatic incident when 11 Turkish officers were detained by US soldiers in the northern Iraqi city of Sulaymaniyah and taken to Baghdad. The Americans were acting on intelligence reports that the Turkish commandos were plotting to assassinate the Kurdish governor of nearby Kirkuk, although Turkish officials strongly denied the claim. Following reports that US soldiers had handcuffed and placed sacks over the heads of the Turkish Special Forces officers, the incident became a major cause of anti-American feelings. Turkish officials, political parties and non-governmental organizations strongly protested. Democratic Left Party (DSP) Chairman Bülent Ecevit said that the US had 'insulted' Turkey. Nationalist Movement Party (MHP) leader Devlet Bahçeli said 'an apology 
should be made to Turkey' while True Path Party (DYP) leader Mehmet Ağar said 'it is an incident over which an ultimatum should be made'.

Turkey was also extremely concerned about reports of a Kurdish advance to Kirkuk backed by US Special Forces. In contacts with US officials and representatives of the two Kurdish groups that had de facto control of northern Iraq, Turkish military officials stressed that Turkey's 'red lines' were still in effect. The Turkish army would directly send troops to northern Iraq if the Kurds declared administration over the city, or if the Turkoman population based in the region was attacked by Kurdish fighters, or in the event of any attempt to change the 'demographic structure of Kirkuk' - a reference to any massive Kurdish inflow into the city.

One other important sensitivity of Turkey concerned the position of the Partiya Karkaren Kurdistan (PKK). The US-led administration in Iraq said that the selfstyled People's Congress of Kurdistan (KONGRA-GEL), the brand new organization which had replaced the terrorist Kurdistan Freedom and Democracy Congress (KADEK), was a terrorist organization and would be treated as such by US forces in Iraq. However, in reality, the USA was not very determined to address the PKK issue. Their tolerance towards the two Kurdish groups, namely the Patriotic Union of Kurdistan (PUK) and the Kurdistan Democratic Party (KDP) meant that they indirectly ignored the PKK problem because both Kurdish groups tolerated the PKK presence in their region so as to avoid violent PKK reprisals. According to Kapsis, 'the Pentagon and the State Department admitted that the USA had neglected to address this issue since they stated that they did not have the troops to carry out the job'. ${ }^{53}$

The issue of anti-Americanism was further debated both in Turkey and the United States with the release of data from two public opinion polls conducted by the Marshall fund and the BBC in a number of countries. In both polls, Turks ranked highest with 82 per cent claiming to be anti-American. Coupled with the pervasiveness of anti-American conspiracy theories in the Turkish media - ranging from accusations that the US military committed genocide in Falluja, to suggestions that the Bush Administration cooked up the South Asian tsunami - these popular trends in Turkey alarmed Washington. ${ }^{54}$

High-ranking policy-makers in the US administration, including Secretary of State Condoleezza Rice and the Deputy Secretary of State Marc Grossman, expressed concern about rising anti-Americanism among both Turkish politicians and the Turkish media, and he stated that 'although the USA realizes the fact that Iraq is a debated issue in Turkey, while dealing with these issues, one should still take into consideration the facts and behave as an ally'. ${ }^{55}$ The same sort of concern was also voiced by the US Department of Defense: the deputy secretary of defense stated that 'Turkish officials should find a solution to end the anti-American feelings among the Turkish people'. ${ }^{56}$ Yet the official Turkish view was that 'it is not a matter unique to Turkey and that anti-Americanism has been caused by the fact that the USA is a country at war, so it is normal that these tendencies may occur'. It was added that anti-American feelings were no less in Turkey than those in some other European countries such as Greece, Germany and France'. ${ }^{57}$

It is possible to conclude that the dynamics of the Turkish-US alliance have changed to a great extent, especially in the post-9/11 period. As the Pew Survey indicates, Turkey is among the top five countries which worry about the potential US military threat. Turkey seems to be pursuing a more independent and assertive 
foreign policy and seems to be very sensitive to allowing the use of Turkish bases in actions in the Middle East and the Gulf, except when these operations are seen clearly to serve Turkish national interests. In short, Turkey is becoming an independent security actor in the region. ${ }^{58}$

Yet one should be cautious about using the term 'anti-Americanism' to label the recent phase of Turkey's stance towards the USA, since in general the survey results indicated that Turkish public opinion also has sympathy towards American culture, ideas about democracy and business practices, although the Turkish people dislike the spread of American ideas and culture. ${ }^{59}$ According to some surveys, such as the one conducted by Poll Mark Company, Turkish people do not hate Americans, but an overwhelming majority of them do not approve of President George W. Bush's policies. According to this survey, 81.5 per cent of respondents are not happy about Bush's policies while only 5.6 per cent approve of President Bush. On the other hand, 64 per cent of respondents have no problem with having an American neighbour. ${ }^{60}$ Another poll, conducted by Ankara-based think tank ISRO (International Strategic Research Organization), indicated that 91 per cent of respondents disapprove of Bush's policies compared to the previous president, Bill Clinton, who had a 49 per cent disapproval rate. Regarding the reasons for the rise of anti-Americanism in Turkey, the same poll indicated that 75 per cent of the respondents see the biggest problem for Turkish-American relations as the American attitude towards the PKK terror organization in Northern Iraq. ${ }^{61}$ They think that President Bush prevented Turkey from carrying out military operations against this organization, and that while Turkey had fully supported American declarations of a 'war on terrorism' and had sent military personnel to Afghanistan, the USA had not been willing to show the same kind of cooperation against the PKK terrorist organization. ${ }^{62}$

In the past few years, the Turkish media has also grown increasingly antiAmerican. The Turkish media of all ideological perspectives attack the USA. For example, in the pan-Islamist daily Milli Gazete, columnist Süleyman Arif Emre wrote: 'As we know, Germany's Hitler started World War II, and about 50 million people perished because of Hitler's ambitions. Bush is America's Hitler. Like Hitler, he too has become a curse for the world. If the world's sensible leaders don't unite against Bush to stop him, a great number of people will die because of his ambitions. ${ }^{63}$ In the same newspaper, columnist Burhan Bozgeyik wrote: 'At present, the American administration is in the hands of the worst enemies of Islam. Their hate is so deep that no amount of Muslim blood [spilled by them] satisfies them. Tens of thousands, even hundreds of thousands of (Muslim) dead, seem little for them. ${ }^{64}$ Criticizing the attitude of Condoleezza Rice, Nuray Mert commented in Istanbul daily Radikal that 'It is possible to be a bully and oppressor with all of these [education, etc.], just as it is possible to oppose oppression while lacking them. History is filled with intelligent, educated, aesthetic - and art-loving fascists. Rice is one of the last and best examples of these. Highly intelligent, very educated, multilingual, a good sportsperson, even a concert pianist - she is a female bully! ${ }^{65}$

A new film released in 2006 and reflecting the increasing wave of antiAmericanism attracted record audiences in Turkey and drew approving comments from Emine Erdoğan, the wife of Prime Minister Recep Tayyip Erdoğan. Gumchewing US soldiers shoot Iraqis in cold blood at a wedding in one scene from the movie. In another scene, set in Abu Ghraib prison near Baghdad, a Jewish-American 
doctor harvests Iraqi prisoners' kidneys for sale to Israel and the West. Valley of the Wolves: Iraq fictionalizes the arrests of members of a Turkish military mission in Iraqi Kurdistan in 2003 (mentioned above). Suspected of plotting to assassinate a Kurdish politician, the 11 men had sacks placed over their heads by US soldiers before being taken to Baghdad for questioning. In real life, Turks could do nothing but fume at what they perceived as a grave insult to their country's most respected institution: the army. In the film however, one character, Alemdar, takes singlehanded revenge on the perpetrators of the slight, before bringing peace to Iraq. The significance of the film Valley of the Wolves was that it is not the work of independents or amateurs. With a budget of $\$ 10$ million, it was the biggest-budget Turkish film in history. It also involved an international cast including the Hollywood actor Billy Zane of the film Titanic. Within three days of its release, the movie had been seen by 1.2 million people, a 40 per cent increase on the previous viewing record. Emine Erdoğan stated 'I feel so proud of them all'. While Foreign Minister Abdullah Gül insisted that the film was no worse than some of the productions of Hollywood studios, Turkish parliament leader Bülent Arınç praised its 'realism'. US officials in Turkey laughed off the significance of the film, but a senior Washington official expressed concern about its success in a secular Muslim country with a US alliance since the early 1950s. 'Can you imagine the First Lady or the head of the House of Representatives going to the gala performance of a film that could incite anti-Turkish feeling among Americans?' the official asked. ${ }^{66}$

Recently published in Turkey, Metal Storm, authored by two young men Orkun Uçar and Burak Turna, is a political fiction based on a scenario where US troops stationed in Iraq clash with a Turkish military unit, leading to an all-out war between the United States and Turkey. While Turkey is bombarded and invaded by the US Army, a Turkish spy retaliates by detonating two briefcase-sized nuclear bombs in Washington DC and New York. The book not only sold much better than expected, it was also received as a plausible scenario, a political manifesto that satisfied the psychological mood and desire of Turks to vent their feelings against American policies in their part of the world. As the opinion polls discussed previously show, Turks are suspicious of American political and military intentions in the Middle East as well as in their own country. They feel indignant because of the insulting and patronizing attitude of American diplomats since the rejection of the resolution by the Turkish Parliament to allow the passage of American troops into Iraq through Turkey, in March 2003. ${ }^{67}$ The New York Times recently editorialized, 'At no period in Turkey's history has there been such antipathy toward the United States. ${ }^{98}$

As can be seen from the account above, the reasons for the rise of antiAmericanism in Turkey since the beginning of the century have mostly to do with the war on Iraq. By patronizingly considering Turkey as an automatic part of its warfighting strategy, the US caused increased anti-Americanism within Turkish society. Related to that, Turkish society was not convinced that it was a 'just war'. In addition, the rise of anti-American sentiments in Turkey during the war on Iraq were the result of the US government's messianic attitude, its projection of omnipotence and its violation of the sovereignty of other nations. ${ }^{69}$ Criss asserts that projecting this omnipotent image usually results in higher expectations than even the United States is capable of delivering, and so, ironically, it results in others' asking why this mighty power can not deliver justice on other issues. ${ }^{70}$ 
Second, it can be concluded that the conventional US belief that Turkey can be coopted by money did not work and on the contrary increased anti-Americanism. ${ }^{71}$ In particular, because of the remark by President George W. Bush, comparing the tough bargaining between Turkey and the US to 'horse trading the Texans have been very good at', the nature of the economic and political relations between the two countries was placed at the centre of discussions. The debate was fuelled by media coverage in Turkey and the United States and caricatures where Uncle Sam was depicted shoving dollar bills down the cleavage of a Turkish belly-dancer. It brought about discussion of 'money for blood' and it backfired, as the Turkish public perceived the situation as a matter of honour and therefore rejected the monetary aid offered by the USA.

Third, as Taşpınar argues, Turkey became important for American foreign policy in the aftermath of $9 / 11$ not because of 'where it was located' but because of 'what it was'. In other words, Turkey's importance was increasing not only in geo-strategic context, but also due to its political and civic identity as well as its democratic, secular and Western presence. ${ }^{72}$ However, Turkey rejects a 'moderate Islamic' tag, stating that it is a secular and democratic state. Therefore, apparent efforts to boost Turkey as a country where Islam and democracy can successfully co-exist and could play a central role in the US-led greater Middle East initiative were challenged by the Turkish secular elite. This elite, although seeing that such an initiative aiming at encouraging democratization in the Muslim regions was useful and appropriate, believed that Turkey would not be a model of a moderate Islamic country in the project and that Turkey had no claim to be a model country. ${ }^{73}$ Then Secretary of State Colin Powell's reference to Turkey in April 2004 as an 'Islamic Republic' illustrates Turkey's sensitivity regarding the matter. The statement provoked widespread criticism from Turkey, and American officials were reminded that Turkey was a secular democracy in which religion was a private affair.

Fourth, the growing link established between the USA and PKK terrorism by people on the street has been a major catalyst behind the rise of anti-Americanism in Turkey. The example of the masses that attended the funeral of one of the ten people killed by suspected PKK bombings in south-eastern Turkey is a striking example. The people were shouting 'down with the PKK, down with the USA'. ${ }^{74}$ Kapsis argues that the United States viewed the PKK as a terrorist group, yet it never regarded the PKK as a bigger threat than the Iraqi regime since the primary concern of the USA in Iraq until 2003 was to contain Saddam's regional power and prevent his regime from acquiring weapons of mass destruction. ${ }^{75}$ During the war as well, Turkey's most pressing security priority was the PKK, whereas the Americans placed eliminating the Iraqi insurgency, training Iraqi troops and protecting an Iraqi constitutional compromise higher on their to-do list. ${ }^{76}$

According to Doğu Ergil, the reason for the rise of anti-Americanism in Turkey is the extraordinary convergence of three factors: first, divergent and conflicting groups converged on the criticism of American policies; second, both factions of the right wing - the ultra-right and the religious right - have also become intensely antiAmerican; third, the secularists - both left and right - have also started to display an anti-American stance. ${ }^{77}$ In short, all segments of Turkish society as well as the state have become intensely critical of American policies to an extent that has not been seen before. 
The future of anti-Americanism in Turkey will be determined to a great extent by the role that the USA would like to assume in the world as well as in the Middle East. The US policy towards Iraq, and the Kurdish issue in particular, will continue to pose the most important challenge to US-Turkish relations in the near future as the uncertainty in Iraq regarding the status of the Kurds continues. Turkey is very concerned about the massive Kurdish migration into some cities such as Kirkuk as it will endanger the future existence of Turkomens in the region. A possible military intervention of Turkey in Northern Iraq may further entangle relations and raise anti-Americanism to further heights.

It is important to note, on the other hand, that a reversal of anti-American feelings is not out of the question and will depend on changes within America as well as of its foreign policy on matters that are of concern for Turkey.

\section{Notes}

The author gratefully acknowledges the support provided by the Turkish Academy of Sciences (GEBIP) programme in the research for this article.

1. J, de Novo, American Interests and Policies in the Middle East 1900-1939 (Minneapolis: The University of Minnesota Press, 1963), p.254.

2. B. Kuniholm, 'Turkey and the US: Views and Expectations', in Turkish-American Relations: Forty Years of Continuity and Change (Istanbul: Fatih Genclik Vakfı Matbaa İsletmesi, 1987), p.31.

3. Mosul was an oil-rich province in northern Iraq. The question of who would control Mosul was not solved in the Lausanne Conference since Great Britain did not want to leave Mosul to Turkey under the pretext that it was highly populated by the Kurds. The problem was later resolved through the League of Nations in 1926 and Mosul became a part of Iraq.

4. De Novo, American Interests and Policies in the Middle East 1900-1939, p.192.

5. Foreign Affairs and National Defence Division, US Military Installations in NATO's Southern Region (Washington DC: US Government Printing Office, 1986), p.45. The establishment of these installations through bilateral defence agreements was justified on the basis of Article III of the North Atlantic Treaty.

6. M. Toker, 'Turkish-American Relations, A Personal View', in Turkish-American Relations: Forty Years of Continuity and Change, p.115. Ferenc Vali points to the same fact that 'fifty-five agreements were concluded through 1964 relating to the military presence of the USA on Turkish soil ... Most of these agreements have never been submitted for approval to the Turkish Parliament or even made public.' F.A. Vali, Bridge across the Bosporus: The Foreign Policy of Turkey (Baltimore, MD: The Johns Hopkins Press, 1971), p.139.

7. N. Uslu, Türk-Amerikan Illiskileri (Ankara: 21. Yüzyıl Yayınları, 2000), p.101.

8. N.B. Criss, 'Strategic Nuclear Missiles in Turkey: The Jupiter Affair', The Journal of Strategic Studies, Vol.20, No.3 (1997), pp.98-103.

9. W. Hale, Turkish Foreign Policy 1774-2000 (London: Frank Cass, 2000), p.135.

10. N.B. Criss, 'A Short History of Anti-Americanism and Terrorism: The Turkish Case', Journal of American History, http://www.historycooperative.org/journals/jah/89.2/criss.html.

11. Vali, Bridge across the Bosporus, p.54.

12. Ibid.

13. 'US Department of State, Press Release No.108, 2 April 1970', cited in G.S. Harris, Troubled Alliance. Turkish-American Problems in Historical Perspective 1945-1971 (Washington DC: AEI-Hoover Policy Studies, 1972), p.12.

14. Uslu, Türk-Amerikan Illiskileri, p.236.

15. 'Letter sent by the US President Lyndon Johnson to Turkish Premier İsmet İnönü', in Appendix B of M. Stearns, Entangled Allies: US Policy towards Greece, Turkey and Cyprus (New York: Council on Foreign Relations Press, 1992), p.157. 
16. Faruk Sönmezoğlu cites George Ball who described the letter as 'the most vulgar diplomatic wording I have ever seen in my life', see F. Sönmezoğlu, İkinci Dünya Savasından Günümüze Türk Dı̧s Politikası (Istanbul: Der Yayınları, 2005), p.72.

17. Harris, Troubled Alliance, p.125.

18. D. Sezer, Kamuoyu ve Dıs Politika (Ankara: Siyasal Bilgiler Üniversitesi Yayınlar1, 1972), pp.371-2.

19. Vali, Bridge across the Bosporus, pp.141-2.

20. A.B. Pakel, 'Turkish-American Relations, 1945-1980' (Unpublished Masters Thesis, Bilkent University, 2006), p.59.

21. Ibid.

22. Harris, Troubled Alliance, p.139.

23. Vali, Bridge across the Bosporus, p.143.

24. Congressional Research Service, Congressional-Executive Relations and the Turkish Arms Embargo (Washington DC: US Government Printing Office, 1984), p.33.

25. N.B. Criss, 'Mercenaries of Ideology: Turkey's Terrorism War', in B. Rubin (ed.), Terrorism and Politics (New York: St. Martin's Press, 1991), pp.123-50.

26. Ibid.

27. CSIA European Security Working Group, Instability and Change on NATO's Southern Flank, p.167.

28. D.A. Rustow, Turkey: A Forgotten Ally (New York: Council on Foreign Relations, 1987).

29. Vali, Bridge across the Bosporus, p.144.

30. Ibid., pp.144-6.

31. For a more detailed analysis of the problems between Turkey and the USA during the post-Cold War period, see A. Güney, 'An Anatomy of the Transformation of the US-Turkish Alliance: From "Cold War" to "War on Iraq"”, Turkish Studies, Vol.6, No.3 (2005), pp.341-59.

32. President Bush's 4 May 1990 speech at Oklahoma State University.

33. Colin Powell quoted in T.G. Carpenter, America Entangled: The Persian Gulf Crisis and its Consequences (Washington, DC: Cato Institute, 1991), p.13.

34. R.F. Grimmet, CRS Report for Congress: Military Assistance to Base Right Countries. (Washington, DC: Library of Congress, 29 January 1993), p.5.

35. US Congress, Senate, Committee on Foreign Relations, Security and Development Assistance: Hearings before the Committee of Foreign Relations, 100th Cong, 1st Session, Part 1, 24, 25, 26 February and 10 March 1987, p.394.

36. For details of America's international strategy, see the documents, 'Overview of America's National Strategy' and 'Prevent our Enemies from Threatening US, our Allies, and Our Friends with Weapons of Mass Destruction', Speech by President Bush, West Point, New York, 1 June 2002, 'Strengthen Alliances to Defeat Global Terrorism and Work to Prevent Attacks against US and Our Friends', Speech by President Bush (Washington, DC, The National Cathedral, 14 September 2001).

37. C.L. Powell, 'A Strategy of Partnerships', Foreign Affairs, Vol.83, No.1 (2004), p.25.

38. United States Mission to the European Union, 'Wolfowitz on Turkey and the EU, Role in Iraq', http://www.useu.be/Categories/US\&EUEnlarg/Dec0302WolfowitzTurkeyEUIraq.htm, 3 December 2002, p.1.

39. 'Turkey and the United States: The End of the Dance', The Economist, 1 March 2003.

40. 'Turkey Drags Feet on Formal Backing for US as time ticks away', Turkish Daily News, 11 January 2003.

41. For a detailed account of this period and the events see Güney, 'An Anatomy of the Transformation of the US-Turkish Alliance'.

42. Turkish Daily News, 10 January 2003.

43. 'The New York Times author William Saphire Threatens Turkey', Turkish Daily News, 16 January 2003.

44. L. Boulton and J. Harding, 'US Threatens to Cancel Turkey's Military Aid', Financial Times, 19 February 2003, http://www.informationclearinghouse.info/article1517.htm, p.1.

45. Turkish Daily News, 8 March 2003.

46. Turkish Daily News, 16 March 2003.

47. Turkish Daily News, 16 March 2003.

48. 'Bush Warns Turkey off Iraq', BBC News, 24 March 2003, http://news.bbc.co.uk/2/hi/europe/ 2879299.stm.

49. Turkish Daily News, 28 October 2003. 
50. Turkish Daily News, 6 November 2003.

51. Turkish Daily News, 28 January 2004.

52. Ibid.

53. J.E. Kapsis, 'From Desert Storm to Metal Storm: How Iraq has spoiled US-Turkish Relations', November 2005, http://www.wws.princeton.edu/research/papers/11_05.jk.pdf, p.387.

54. Ibid., p.380.

55. 'ABD’nin Amerikan Karşıtlığı Kaygısı', 11 February 2005, http://www.ntvmsnbc.com/news/ 309084.asp.

56. 'Amerikan Karşıtlı̆̆ı Uyarısı', Sabah (Istanbul Daily), 19 February 2005, http://arsiv.sabah.com.tr/ 2005/02/19/gnd93.html.

57. Ibid., p.2. See the response of the AKP deputy, Egemen Bağıș. See also U. Ziyal, 'Türkiye'de Amerikan karşıtlı̆̆ Yok', http://www.voanews.com/turkish/archive/2003-06/a-2003-06-17-3-1.cfm.

58. E.J. Erickson, 'Turkey as a Regional Hegemon-2014: Strategic Implications for the United States', Turkish Studies, Vol.5, No.3 (2004), p.43.

59. E. Erdogan, 'The Missing Element: Turkish Public Opinion Towards the USA', Turkish Policy Quarterly, Vol.4, No.1 ( 2005), p.201.

60. I. Bal, 'US Fury on "Anti-Americanism in Turkey",, The Journal of Turkish Weekly, http:// www.turkishweekly.net/editorial.php?id=11, p.1.

61. Ibid., p.2.

62. Ibid., p.3.

63. S.A. Emre, 'America's Hitler', http://www.freerepublic.com/focus/f-news/1351118/posts, p.2.

64. B. Bozgeyik, 'The Pervert Enemies', in ibid., p.2.

65. N. Mert, 'The Black 'Occupier”' Women', in ibid., p.3.

66. http://www.washtimes.com/world/20060214-104958-5445r.htm.

67. D. Ergil, 'Anti-Americanism', Turkish Daily News, 21 February 2005, http://www.turkishdailynews. com.tr/article.php?enewsid=6451, pp.2-3.

68. Ted Widmer, New York Times article on 'Metal Firtina: Death to the Crusade', 15 September 2005, http://mbarchives.blogspot.com/2005/09/nytimes-article-on-metal-firtina-death.html.

69. Criss, 'A Short History of Anti-Americanism', p.9.

70. Ibid.

71. Erickson, 'Turkey as a Regional Hegemon-2014', p.39.

73. Ö. Taşpınar, 'The Anatomy of anti-Americanism in Turkey', Brookings Institution, http:// www.brookings.edu/views/articles/fellows/taspinar20051116.pdf, p.9.

73. Turkish Daily News, 1 March 2004.

74. A. Eisele, 'The Hill Interview: Anti-Americanism Growing in Turkey Partly because of Iraq War, Official Says', The Hill, http://www.hillnews.com/thehill/export/TheHill/News/Frontpage/092606/ turkey.html, pp.2-3.

75. Kapsis, 'From Desert Storm to Metal Storm', p.381.

76. Ibid.

77. Ergil, 'Anti-Americanism', pp.2-3. 